\title{
MEDIA PEMBELAJARAN BAHASA ARAB BERBASIS DIGITAL 4.0 (KAHOOT DAN SOCRATIVE) PADA SEKOLAH DASAR
}

\author{
${ }^{1)}$ Fashi Hatul Lisaniyah, Pendidikan Agama Islam, IAINU Tuban, email : \\ fashihatullisaniyah@stitmatuban.ac.id \\ ${ }^{2)}$ Ummidlatus Salamah, Pendidikan Agama Islam, IAINU Tuban, email : \\ ummidlatussalamah@stitmatuban.ac.id
}

\begin{abstract}
This study aims to describe Arabic language learning media era 4.0 from conceptual and actual aspects and focuses on media learning Arabic language specifically elementary school (Junior hight school). The approach of this study is (library research) by discussing literatures that discuss arabic language learning media. Conclusion of this study is innovation of learning, especially in Arabic language lessons, is something important and must be owned or done by arabic teachers. This is because learning will be more enjoyable and meaningful for students. With kahoot and socrative media, it is expected to encourage students to be more enthusiastic and happy to learn Arabic. As a teacher who interacts with students every day, it is not wrong to constantly innovate in learning. Entering this 4.0 era, teachers are required to keep trying to find, explore and find breakthroughs, approaches, methods and learning media is one of the supporting new media that will be fresh and enlightening. This article describes the media of Arabic language learning for the basic level, covering the learning media of Kahoot and Socrative. The more creative and innovative a teacher is in using learning media will make it easier to deliver Arabic lessons, the easier it is for students to receive Arabic lessons. This is a major factor in the success of MI-level Arabic lessons.
\end{abstract}

Keywords: Learning Media, Arabic Language, Junior High School.

\section{Pendahuluan}

Seiring dengan perkembangan globalisasi, Arus globalisasi saat sekarang ini menimbulkan banyak sekali perubahan ditengah-tengah masyarakat. Perubahan sosial yang terjadi tidak bisa dihindari karena pesatnya kemajuan pengetahuan dan teknologi. Sehingga hal ini berdampak pada seluruh aspek kehidupan manusia, termasuk dalam aspek pendidikan. Berdasarkan kenyataan tersebut, pada era global ini diperlukan adanya inovasi dalam dunia pendidikan yang khususnya inovasi dalam media pembelajaran. Inovasi pendidikan selalu menjadi tema yang menarik untuk didiskusikan dari masa kemasa. Dalam Inovasi pendidikan termasuk inovasi dalam media pembelajaran sangat diperlukan dalam pendidikan dalam rangka memenuhi kebutuhan masyarakat dan menjawab tantangan zaman globalisasi, sekaligus mempunyai tujuan untuk memecahkan masalah yang ada.

Pembelajaran adalah dua kegiatan dan melibatkan dua pihak, yaitu kegiatan belajar dan membelajarkan. Sebagaimana Wina Sanjaya mengemukakan bahwa pembelajaran dikatakan 
sebagai suatu sistem karena pembelajaran adalah kegiatan yang bertujuan, yaitu membelajarkan siswa. Proses pembelajaran merupakan rangkaian kegiatan yang melibatkan berbagai komponen yang satu sama lain saling berinteraksi dan berinterelasi, dimana guru harus memanfaatkan komponen tersebut dalam proses kegiatan untuk mencapai tujuan yang ingin direncanakan. ${ }^{1}$ Dalam hal ini siswa menjadi fokus utama sebagai pelaku belajar, sedangkan guru sebagai pihak yang menjadi fokus untuk menciptakan situasi hingga terjadinya proses belajar pada siswa. Dalam proses pembelajaran pada dasarnya menuntut kemampuan guru dalam mengendalikan kegiatan belajar siswa. Meski setiap kegiatan belajar siswa tidak selalu bergantung kepada kehadiran guru, namun terdapat hubungan sebab akibat antara guru mengajar dan murid belajar. Oleh karena itu, salah satu tanggung jawab seorang pendidik dalam hal ini yaitu guru, dalam proses pembelajaran adalah dengan merancang dan melaksanakan proses pembelajaran sebaik mungkin sehingga para peserta didik dapat mencapai tujuan yang telah ditetapkan.

Pendidikan merupakan subsistem dalam pendidikan universal diharapkan mampu memebrikan kontribusi positif karena keberadaannya sebagai arena riset masa depan (significance of future). Sistem pendidikan dalam bahasa Arab diharapkan tidak hanya sebagai penyangga nilai-nilai, tetapi sekaligus sebagai penyeru pikiran - pikiran produktif dan berkolaborasi dengan kebutuhan zaman. Dari sinilah terlihat bahwa pendidikan, tak terkecuali pembelajaran bahasa Arab mengalami dinamika, sekaligus pentingnya adanya inovasi dalam media pembelajaran bahasa Arab.

Setiap pembelajaran bahasa, tidak akan lepas oleh, media pembelajaran agar tujuan dari pembelajaran bahasa tersebut dapat tercapai secara cepat, efektif, dan efisien. Media merupakan faktor penting dalam mendukung proses pembelajaran siswa, media dapat dimaknai sebagai segala sesuatu yang dapat digunakan untuk menyampaikan pesan dan informasi. Dalam meningkatkan kemampuan peserta didik perlu adanya media pembelajaran sebagai penyambung materi yang digunakan dengan hasil kemampuan yang harus dikuasai peserta didik. ${ }^{2}$ Media pembelajaran sesungguhnya merupakan sumber belajar yang dapat berupa bahan, material atau alat dan device yang digunakan untuk berinteraksi antara guru dan murid dalam proses belajar mengajar untuk mencapai tujuan pembelajaran yang berkualitas.

\footnotetext{
${ }^{1}$ Wina Sanjaya, Strategi Pembelajaran Berorientasi Standar Proses Pendidikan (Jakarta: Kencana, 2008), 59.

${ }^{2}$ Akhmad Aji Pradana, \& Jazilatul Ummah. (2020). PENGARUH MEDIA SEMPOA TERHADAP KEMAMPUAN OPERASI HITUNG PENGURANGAN SISWA KELAS II MI . PREMIERE : Journal of Islamic Elementary Education, 2(1), 94-102.
} 
Di sisi lain, Prananto Sukmajaya sebagai seorang pakar teknologi informasi mengatakan bahwa perkembangan teknologi informasi yang begitu mendesak telah menstransformasikan konsep pendidikan berbasis digital. ${ }^{3}$ Teknologi informasi dapat mengintegrasikan komputer, internet maupun sarana sistem informasi lainnya menjadi alat yang memberdayakan proses belajar mengajar lebih kreatif, inovatif, dan kompetitif perkembangan zaman yang menuntut semua. Oleh karena itu, penelitian ini menitik beratkan pada media pembelajaran bahasa Arab berbasis digital menggunakan Kahoot dan Socrative pada sekolah dasar. Hal ni penting untuk dikaji guna memberikan kontribusi bagi perkembangan pembelajaran bahasa Arab yang lebih inovatif dan kompetitif sesuai dengan tuntutan zaman.

\section{Metodologi}

Penelitian ini merupakan penelitian studi pustaka (library research), sumber data diperoleh dari dokumen jurnal penelitian, artikel, dan sumber pustaka lain terkait Media pembelajaran bahasa arab menggunakan Kahoot dan Socrative. Data yang telah terkumpul kemudian akan melalui reduksi data supaya pembahasan menjadi lebih fokus dan bisa menjawab permasalahan yang telah dirumuskan.

Selanjutnya validasi data, menurut Mirshad validasi data dapat ditentukan menggunakan tiga hal: Pertama, kepercayaan, kredibilitas seseorang peneliti sangat dipertanyakan apakah data tepat dalam fokusnya, ketepatan memilih sumber data dan pelaksanaan motode pengumpulan datanya. Analisis data dan interpretasi data, seluruhnya membutuhkan konsistensi satu sama lain. Kedua, keteralihan (transferbility) hasil penelitian yang dikemudian hari dijadikan rujukan kembali pada penelitian yang setema dan dipelajari lebih lanjut oleh peneliti lain. Jika seorang peneliti memahami dan mendapat gambaran yang jelas terhadap hasil penelitian sebelumnya, maka hasil penelitian tersebut sudah memenuhi standar transferbilitas. Ketiga, kebergantungan penelitian terhadap data yang didapatkan, dengan kata lain penelitian adalah hasil rekam jejak dari data yang telah ditelusuri pada referensi kepustakaan. Keempat, kepastian, menguji keabsahan hasil penelitian terhadap kasus atau fenomena yang sudah terjadi, baik secara teoritis atau aplikatif, jika hal tersebut terbukti, maka hasil penelitian bisa dikatakan $\mathrm{absah}^{4}$.

\footnotetext{
${ }^{3}$ Muhandis Azzuhri, metode dan media bahasa arab berbasis internet di era teknologi informasi, Jurnal Insania, Vol. 14 No. 3 2009. Hal 2.

${ }^{4}$ Mirshad, Z. (2014). Persamaam Model pemikiran al-Ghaza dan Abraham Maslow tentang model motivasi konsumsi. Surabaya: Tesis. UIN Suan Ampel Surabaya.
} 


\section{Hasil}

\section{Media pembelajaran}

Kata Media secara bahasa berarti perantara atau pengantar; sedangkan kata pembelajaran diartikan sebagai suatu kondisi yang diciptakan untuk membuat seseorang melakukan suatu kegiatan belajar". ${ }^{5}$ Dengan demikian, media pembelajaran memberikan penekanan pada posisi media sebagai wahana penyalur pesan atau informasi belajar untuk mengkondisikan seseorang untuk belajar. Dengan kata lain, pada saat kegiatan belajar berlangsung bahan belajar (learning matterial) yang diterima siswa diperoleh melalui media. Sedangkan defines media Pendidikan atau media pembelajaran menurut Rossi dan Breidle dalam bukunya Wina Sanjaya menyatakan bahwa media pembelajaran adalah seluruh alat dan bahan yang dapat dipakai untuk mencapai tujuan dalam Pendidikan seperti radio, televisi, buku, koran, majalah dan sebagainya. ${ }^{6}$

Terjadinya belajar bermakna ini tidak terlepas dari peran media terutama dari kedudukan dan fungsinya. Secara umum media mempunyai kegunaan:

1) Memperjelas pesan yang ingin disampaikan agar tidak terlalu verbalistis.

2) Mengatasi keterbatasan ruang, waktu tenaga dan daya indra.

3) Menimbulkan semangat belajar, interaksi lebih langsung antara murid dengan sumber belajar.

4) Memungkinkan agar anak belajar mandiri sesuai dengan bakat dan kemampuan visual, auditori \& kinestetiknya.

5) Memberikan rangsangan yang sama, mempersamakan pengalaman \& menimbulkan persepsi yang sama. ${ }^{7}$

Dengan demikian, tujuan pemanfaatan media dalam proses pembelajaran adalah untuk mengefektifkan dan mengefisienkan proses pembelajaran itu sendiri ${ }^{8}$.

Media mempuanyai karakteriktis dan kegunaan masing - masing, maka seorang guru perlu memperhatikan agar mereka dapat memilih media mana yang sesuai dengan kondisi dan kebutuhan. Sebagai contoh media berbasis digital yaitu Kahoot dan Socrative dengan tampilan yang sangat bagus variative dan bisa disesuaikan dengan kebutuhan, sehingga pengajaran bahasa

5 Cepi Riyana, "Strategi implementasi Teknologi Informasi dan Komunikasi dengan menerapkan Konsep Instructional Technology”, Jurnal Edutech, Jurusan Kurtek Bandung, 2004 hal 5.

${ }^{6}$ Wina Sanjaya,2006, Strategi Pembelajran Berorientasi Standar Proses Pendidikan, (Jakarta: Prenada Media Group, 2006) cet, hal 163.

${ }^{7}$ Cepi Riyana, Op. Cit., hal 6.

${ }^{8}$ Nurjanah, S. (2020). Pengembangan Media Pembelajaran Teka-Teki Silang (TTS) Pada Pembelajaran Tematik Tema Cita-Citaku Kelas IV Di MI Al Busyro. Premiere: Journal of Islamic Elementary Education, 2 (1), hal.3. 
asing khususnya dalam pembelajaran Bahasa arab, media ini tergolong tepat, apalagi untuk anak sekolah dasar yang sangat suka dengan media yang interaktif.

Beberapa pendapat ahli telah mengelompokkan macam-macam media. Dengan ini, guru dapat selektif untuk menggunakan media sesuai dengan tujuan pembelajaran, materi dan kondisi psikologis siswa khususnya siswa sekolah dasar/madrasah Ibtidaiyah. Namun demikian, dari beberapa pengelompokan tersebut dapat kita simpulkan bahwa media terdiri atas ${ }^{9}$ :

1. Media visual: yaitu media yang hanya dapat dilihat, yang termasuk kelompok visual, seperti foto, gambar, poster, grafik, kartun, liflet, buklet, torso, film bisu, model 3 dimensi seperti diorama dan mokeup.

2. Media Audio: adalah media yang hanya dapat didengar saja, seperti kaset audio, radio, MP3 Player, iPod.

3. Media Audio Visual: yaitu media yang dapat dilihat sekaligus dapat didengar, seperti film bersuara, video, televisi, sound slide,

a) Multimedia: yaitu unsur media secara lengkap seperti suara, animasi, video, grafis dan film. Multimedia sering diidentikan dengan komputer, internet dan pembelajaran berbasis computer.

b) Media Realita: yaitu semua media yang ada di lingkungan nyata di alam, baik digunakan dalam keadaan hidup maupun sudah diawetkan, seperti tumbuhan, batuan, binatang, insektarium, herbarium, air, sawah dan sebagainya.

Media menghadirkan nilai-nilai praktis dalam proses kegiatan pembelajaran yaitu sebagai berikut:

1. Media pembelajaran bisa membantu mengatasi keterbatasan pengalaman yang dimiliki para siswa.

2. Media yang disajikan dapat melampaui batasan ruang kelas.

3. Media pembelajaran memungkinkan adanya interaksi antara peserta didik dengan lingkungannya.

4. Media yang disajikan dapat menghasilkan keseragaman pengamatan siswa.

5. Secara potensial, media yang disajikan secara tepat dapat menanamkan konsep dasar yang kongkrit, benar, dan berpijak pada realitas.

6. Media mampu membangkitkan keinginan dan minat baru.

\footnotetext{
${ }^{9}$ Wina Sanjaya, Op. Cit., hal 172.
} 
7. Media dapat membangkitkan motivasi dan merangsang peserta didik untuk belajar.

8. Media dapat memberikan belajar secara integral dan menyeluruh dari yang kongkrit ke yang abstrak, dari seserhana ke rumit.

Beberapa klasifikasi media pembelajaran tersebut memiliki relevansi jika digunakan dalam pembelajaran Bahasa arab, akan tetapi perlu mempertimbangkan dan menyesuaikan dengan materi dan keadaan siswa yang akan diajarkan, supaya media yang diterapkan benar-benar dapat membantu dan mempermudah pendidik dalam menyampaikan materi.

Dalam memilih media untuk kepentingan pengajaran menurut Nana Sudjana \& Ahmad Riva sebaiknya memperhatikan kriteria-kriteria sebagai berikut:

a) Ketepatannya dengan tujuan pengajaran, artinya media pengajaran dipilih atas dasar tujuan - tujuan instruksional yang telah ditetapkan. Tujuan - tujuan intruksional yang berisikan unsur pemahaman, aplikassi, analisis, sinteis lebih memungkinkan digunakannya media pengajaran.

b) Dukungan terhadap isi bahan pengajaran, artinya bahan pelajaran yang sifatnya fakta, prinsip, konsep, dan generalisasi sangat memerlukan bantuan media agar lebih mudah dipahami oleh siswa.

c) Ketrampilan guru dala menggunakannya. Apapun tujuan dan jenis media yang diperlukan, syarat utama guru dapat menggunakan dalam proses pengajaran.

d) Tersedianya waktu untuk menggunakannya, sehingga media tersebut dapat bermanfaat bagi siswa selama pengajaran berlangsung.

e) Sesuai dengan taraf berpikir siswa. Memilih media untuk Pendidikan dan pengajaran harus sesuai dengan taraf berpikir siswa, sehingga makna yang terkandung di dalamnya dapat dipahami oleh para siswa. ${ }^{10}$

Dengan kriteria pemilihan media di atas, seorang guru dapat lebih mudah menggunakan media mana yang dianggap tepat untuk diterapkan dalam pembelajaran dengan tujuan mempermudah pemahaman siswa, dan membantu mempermudah tugas-tugasnya sebagai pengajar.

\section{Pembelajaran Bahasa arab MI}

Bahasa merupakan alat komunikasi atau yang digunakan seseorang kepada orang lain. Bahasa adalah alat komunikasi manusia yang paling utama. Karena tanpa bahasa kita tidak bisa

\footnotetext{
${ }^{10}$ Nana Sudjana \& Ahmad Riva, Media Pembelajaran, (Bandung: Sinar Baru Algensindo, 2009), hal. 5.
} 
berinteraksi dan berkomunikasi dengan orang lain. Sehingga jika terdapat ksealahan dalam penggunaan bahasa akan salah pula dalam pemahaman. ${ }^{11}$

Pembelajaran bahasa Arab harus bisa mendorong siswa dalam mengembangkan ketrampilan berbahasa arab dengan baik. Kemampuan siswa dalam berbahasa Arab serta sikap positif terhadap bahasa Arab tersebut sangat penting bagi siswa dalam rangka membantu memahami Alquran dan hadist sebagai sumber ajaran islam, serta kitab-kitab yang berbahasa Arab yang berkaitan dengan Islam bagi murid ${ }^{12}$.

Oleh karena itu, materi bahasa arab di madrasah ibtidaiyah/sekolah dasar harus sudah mulai dipersiapkan agar anak bisa berbahasa Arab dengan empat keterampilan berbahasa yang diajarkan secara integral, yaitu menyimak, berbicara, membaca dan menulis ${ }^{13}$. Walaupun begitu, pada tingkat/level pendidikan dasar (MI/SD) akan lebih difokuskan pada kemapuan menyimak dan berbicara secara sederhana sebagai dassar landasan berbahasa. Karena anak usia MI/SD harus mempelajari dasar dari bahasa Arab tersebut terlebih dahulu, yaitu memahami dan belajar berbicara agar terbiasa. ${ }^{14}$

Bahasa Arab sangat penting dipelajari sejak dini karena juga sangat penting untuk masa depan anak, sebab:

1. Bahasa Arab adalah bahasa Alquran

2. Dengan memahai bahasa Arab kita juga bisa mempelajari Alqur'an yang menggunakan bahasa arab.

3. Banyak ilmu pendididkan Islam yang disampaikan dengan menggunakan bahasa Arab.

4. Bahasa Arab merupakan bahasa yang indah. Dengan mempelajari bahasa ini, akan mempertajam daya pikir, nilai seni, dan sastra kita.

Di sisi lain, bahasa Arab dapat mempermudah penguasaan terhadap ilmu pengetahuan karena telah menjadi sarana menyampaikan pengetahuan. Bukti konkretnya, banyak ulama yang mengabadikan berbagai disiplin ilmu dalam bentuk syair-syair, dan juga shalawat. Dengan ini,

\footnotetext{
${ }^{11}$ Jago Tarigan, Tehnik Pengajaran Ketrampilan Berbahasa, (Bandung: Angkasa, 1984), hal. 23.

${ }^{12}$ E. Mulyasa, Menjadi Pengajar Profesional Menciptakan Pembelajaran Kreatif dan Menyenangkan, (Bandung: PT Rosda Karya, 2008), hal. 51

${ }_{13}^{13}$ Moch Luklil Maknun, "Buku Bahasa Arab MI di Pekalongan", Jurnal Penelitian, Vol. 11, Mei 2014

${ }^{14}$ Azkia Muharom Albantani, "Pembelajaran Bahasa arab di MI" Attadib Journal of Elementary Education, Vol. 3 (2), Desember 2018. Hal 162.
} 
seseorang akan relatif lebih mudah mempelajarinya karena tertarik pada keindahannya dan menjadi keharusan bagi orang yang benar-benar ingin menguasainya dengan baik.

\section{Media Pembelajaran Bahasa Arab MI berbasis Digital 4.0}

Dalam pembelajaran bahasa Arab SD/MI, media merupakan hal yang sangat berperan penting. Dilihat dari psikologi, media pembelajaran membantu perkembangan psikologis anak dalam belajar. Hal ini dikarenakan secara psikologi alat bantu mengajar yang berupa media pembelajaran sangat memudahkan siswa dalam belajar. Media dapat membuat sesuatu yang abstrak menjadi tampak kongkrit (nyata). ${ }^{15}$ Hal ini sesuai dengan pernyataan Rusyan (1993), pada dasarnya media itu dipakai dalam proses pembelajaran dengan maksud untuk membuat cara belajar yang lebih efektif dan efisien.

Kita mengenal media pembelajaran sebagai segala sesuatu yang dimanfaatkan untuk keperluan pembelajaran baik berbentuk fisik maupun non fisik. Menurut Gagne dan Briggs dalam Arsyad (2014) mengemukakan bahwa media pembelajaran meliputi alat yang secara fisik digunakan untuk menyampaikan isi materi pelajaran. Sedangkan menurut P. Ely dalam Haling (2007) mengemukakan media pembelajaran dalam arti luas yaitu orang, material atau kejadian yang dapat menciptakan kondisi sehingga memungkinkan pebelajar memperoleh pengetahuan, ketrampilan atau sikap yang baru. Ragam media pembelajaran sangat banyak, meliputi teks, audio, peraga, visual, video, software, aplikasi, dan lain sebagainya.

Tantangan yang kita hadapi sekarang adalah kita sedang berada di era industri 4.0 dimana hampir semua kehidupan dikendalikan oleh teknologi termasuk dunia pendidikan. Era 4.0 ditandai dengan beberapa hal. Ditulis oleh Marcel Susanto (2019) di website Zenius.net bahwa kemajuan era industry 4.0 Pertama, "Internet of Things" yaitu Semua kegiatan A sampai Z menggunakan internet. Semua komputer tersambung ke jaringan bersama. Komputer juga semakin kecil dengan munculnya smartphone sehingga kita bisa terhubung dengan seluruh dunia tanpa batas. Kedua, "Big data" yaitu bisa di akses semua orang. Bisa menciptakan 1001 sensor yang mampu merekam segalanya selama 24 jam. Banyak ragam data baru yang muncul. Ketiga, "Cloud Computing" yaitu otomatis disimpan cloud, karena tersambung di internet maka semua data akan disimpan dijaringan yang sangat besar. Ke empat, "Artifical Intelligence" atau

\footnotetext{
${ }^{15}$ Supriyono, pentingnya media pembelajaran untuk meningkatkan Minat belajar siswa sd. Volume II, Nomor 1, Mei 2018. PGSD, FIP, Universitas Negeri Surabaya
} 
kecerdaan buatan, Seperti mesin yang memiliki kemampuan belajar, yang bisa sadar ketika melakukan kesalahan kemudian bisa memperbaikinya. Kelima, "Aplikasi".

Media Pembelajaran Bahasa Arab MI berbasis Digital 4.0 adalah media pembelajaran bahasa Arab untuk tingkat MI/SD yang menggunakan teknologi dan internet dalam setiap proses pembelajarannya. Dalam Pembelajaran Bahasa Arab MI, media pembelajaran berbasis teknologi ini memudahkan proses pembelajaran dari segi efektivitas dan efisiensi. Media pembelajaran berbasis teknologi era digital 4.0 yang dapat digunakan guru dan siswa untuk menunjang proses pembelajaran Bahasa Arab MI yaitu Kahoot dan Socrative.

\section{Media Pembelajaran Bahasa Arab Kahoot}

Kahoot! adalah sebuah media pembelajaran online yang bisa digunakan dalam kegiatan belajar mengajar Bahasa Arab MI dalam rangka mengevaluasi hasil proses belajar bahasa Arab siswa MI, mengulang kembali materi pelajaran Bahasa Arab dan merangsang minat siswa MI untuk melakukan diskusi baik secara kelompok maupun secara klasikal tentang pertanyaanpertanyaan yang diberikan oleh Kahoot! ${ }^{16}$

Salah satu syarat untuk membuat media pembelajaran kahoot adalah dengan memiliki akun gmail. ${ }^{17}$ Media pembelajaran kahoot memiliki beberapa fitur antara lain game, kuis, diskusi, dan survey. Di dalam Fitur game, bisa dibuat pertanyaan terkait materi Bahasa Arab MI dan menentukan jawabannya, serta dapat ditentukan durasi waktu untuk menjawab pertanyaan tersebut. Menariknya dari media pembelajaran bahasa Arab ini, jawaban bisa diwakili dengan gambar dan warna. Siswa MI diminta untuk memilih gambar atau warna yang mewakili jawaban yang benar.

\section{Cara Mengakses Media Pembelajaran Kahoot}

Langkah-langkah dalam mengakses dan menggunakan media pembelajaran Kahoot:

\section{a Sebagai Guru Bahasa Arab MI}

1. Buka browser

2. Ketik https://kahoot.com

\footnotetext{
16 IIrma Rasita Gloria Barus, Tatie Soedewo, Tanpa tahun, Penggunaan Media Kahoot! Dalam Pembelajaran Struktur Bahasa Inggris, ISSBN : 978-602-71928-1-2

${ }^{17}$ www.Ahza.Net diakses hari jumat tanggal 13 November 2020
} 
3. Muncul tampilan awal Kahoot

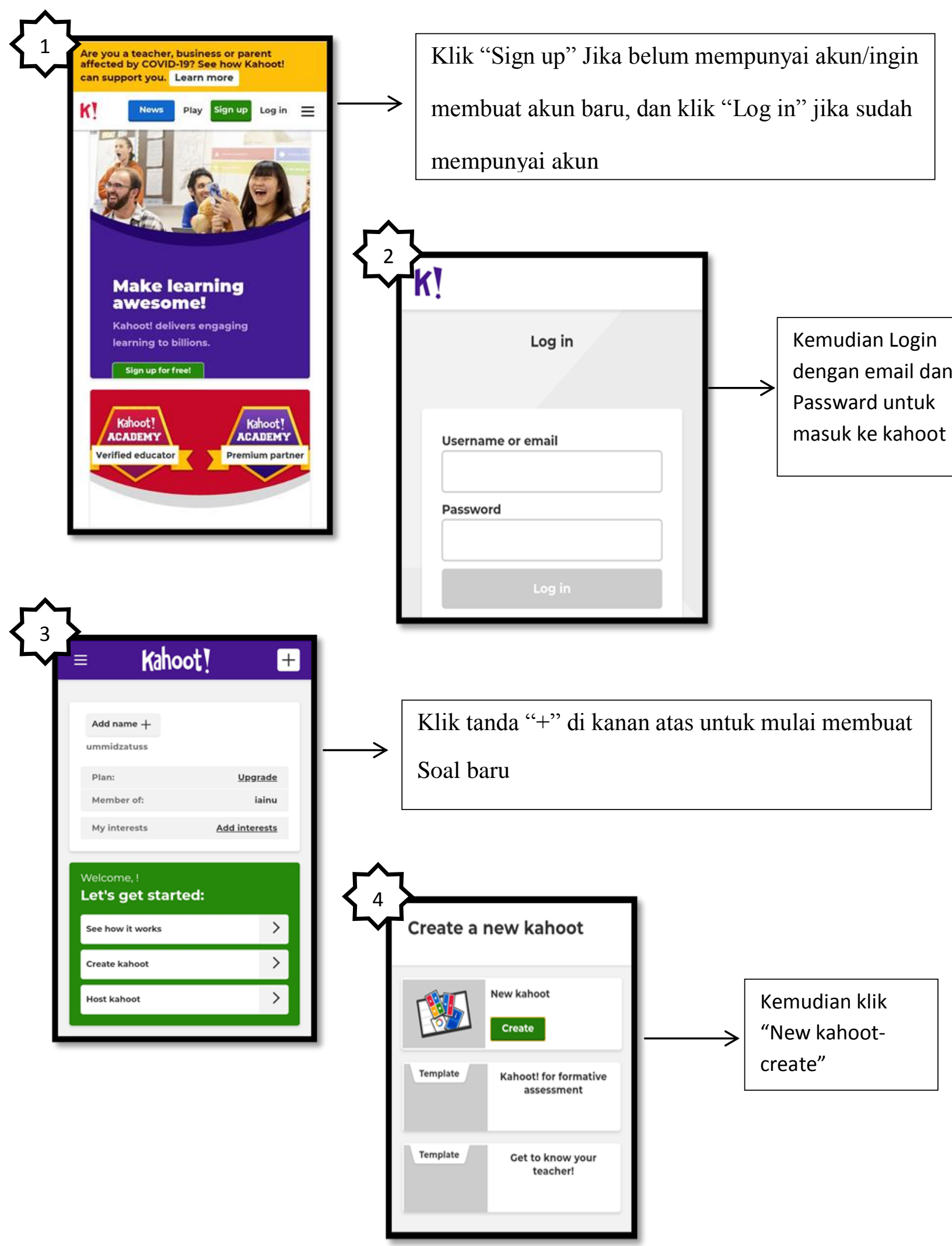




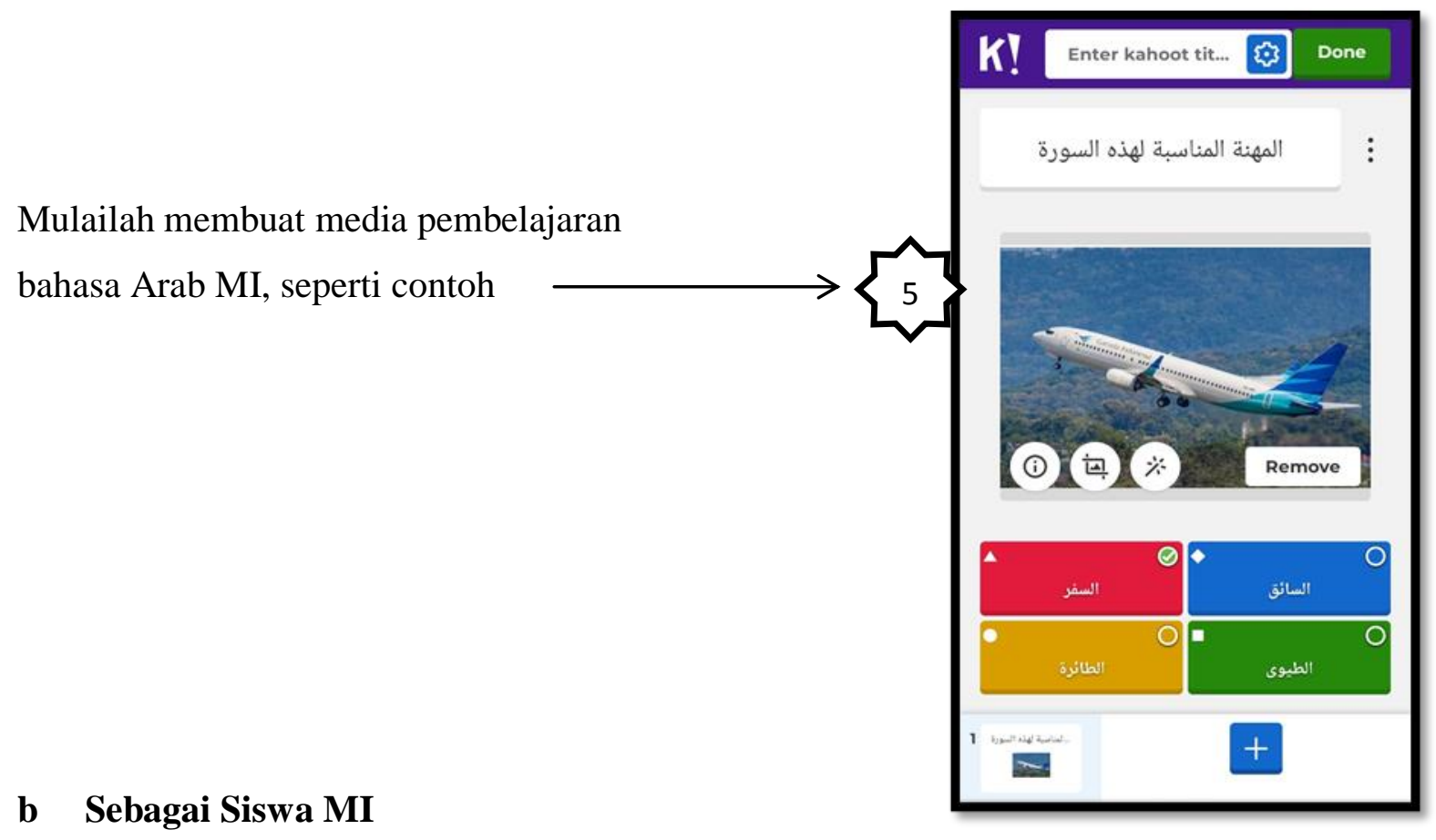

Siswa MI bisa menggunakan media pembelajaran bahasa arab Kahoot melalui smartphone atau laptop untuk mengerjakan latihan-latihan dari Kahoot dengan langkahlangkah sebagai berikut:

1. Buka browser

2. Ketik https://kahoot.it

3. Kemudian masukkan "Game Pin" yang tertera dilayar.

4. PIN didapat dari guru yang membuat media

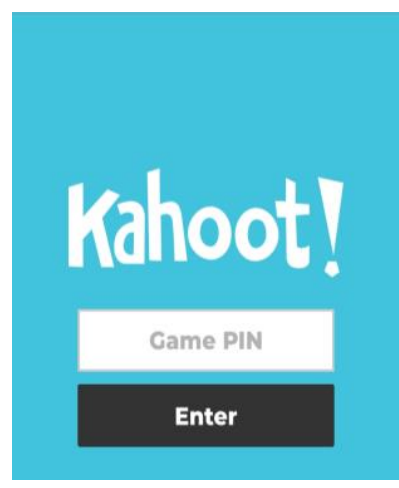

5. Masukkan "Nick Name" dan periksa layar untuk memastikan sudah terdaftar dan bersiapsiap untuk memulai mengikuti game ini.

6. Setelah guru MI dan semua siswa MI siap untuk memulai game ini, guru menekan tombol "start". Pada layar akan tampil sebuah pertanyaan di bagian atas layar dan dibagian bawah terdapat empat atau tiga kotak berwarna-warni yang berisikan pilihan jawaban. Semakin cepat menekan kotak yang berisi jawaban semakin besar kemungkinan untuk berada pada peringkat teratas bila jawaban mereka benar.

7. Sebelum peringkat lima teratas ditampilkan, guru MI dapat membahas soal tersebut terutama apabila siswa MI banyak yang menjawab salah. 
Demikian langkah-langkah cara mengakses dan menggunakan kahoot sebagai media pembelajaran bahasa Arab MI.

\section{Kelebihan dan kekurangan dari Media Pembelajaran Bahasa Arab Kahoot}

Adapun kelebihan dari media pembelajaran kahoot untuk menunjang pembelajaran bahasa Arab MI yaitu Pertama, Suasana kelas ketika pembelajaran menjadi lebih menyenangkan. Kedua, Anak-anak diperkenalkan penggunaan teknologi sebagai media belajar. Ketiga, Melatih kemampuan motorik anak dalam pengoperasikan media pembelajaran bahasa Arab Kahoot.

Sedangkan Kekurangan dari media pembelajaran kahoot sendiri ada beberapa hal yang akan di rasakan oleh guru dan siswa MI yaitu Pertama, Tidak semua guru mengikuti perkembangan teknologi, sehingga kesulitan dalam menggunakan media pembelajaran bahasa Arab kahoot untuk siswa MI. Kedua, sarana prasarana sekolah yang kurang memadai. Ketiga, Anak-anak gampang terkecoh untuk membuka hal lain karena ketika pelajaran terambung dengan internet. Keempat, Durasi pertemuan di kelas yang angat terbatas. Kelima, Tidak semua guru mempunyai waktu yang cukup untuk merancang pembelajaran bahasa Arab dengan media Kahoot.

\section{Media Pembelajaran Socrative}

Socrative merupakan sebuah student response system yang memungkinkan guru untuk membuat kuis atau permainan interaktif dan melibatkan siswa secara langsung (Guraru, 2013). Selain itu, socrative merupakan media sosial yang dapat dimanfaatkan dalam pembelajaran bahasa, dalam pembelajarannya guru dapat memberikan kuis dengan suasana berbeda karena bisa diakses dengan komputer ataupun ponsel siswa. Hal ini membantu interaksi antara guru, siswa dan antarteman sekelas. ${ }^{18}$ Beberapa fitur Socrative antara lain:

- Quiz - Fitur ini memungkinkan guru Bahasa Arab MI untuk membuat kuis pertanyaan pilihan ganda, pilihan benar / salah atau jawaban pendek yang dapat mereka simpan dan gunakan kembali. Di kelas, guru MI membuat kuis dan siswa menyelesaikannya secara real time melalui perangkat mereka.

- Space Race - siswa menyelesaikan kuis dengan cara bersaing satu sama lain untuk mendapatkan reward.

- Quick Question - guru MI menanyakan pertanyaan pilihan ganda, benar / salah atau jawaban pendek secara lisan atau menulisnya di papan tulis. Siswa menggunakan Socrative untuk memilih jawaban yang benar.

\footnotetext{
${ }^{18}$ www,ahza.net/2019, diakses hari jumat tanggal 13 November 2020
} 
- Exit Ticket - siswa merefleksikan di akhir pelajaran. Ada dua pertanyaan bawaan (Seberapa baik Anda memahami materi hari ini? Dan Apa yang Anda pelajari di kelas hari ini?). Guru MI menetapkan pertanyaan ketiga secara lisan atau di papan tulis, yang dapat berupa pertanyaan seperti Apa tiga kata baru yang telah Anda pelajari hari ini? atau Apa yang Anda rasa sulit tentang pelajaran hari ini?

\section{Cara Mengakses Media pembelajaran Bahasa Arab Socrative}

\section{a Sebagai Guru Bahasa Arab MI}

1. Buka browser

2. Ketik https://socrative.com,

3. Perhatikan gambar dan petunjuk di bawah ini:

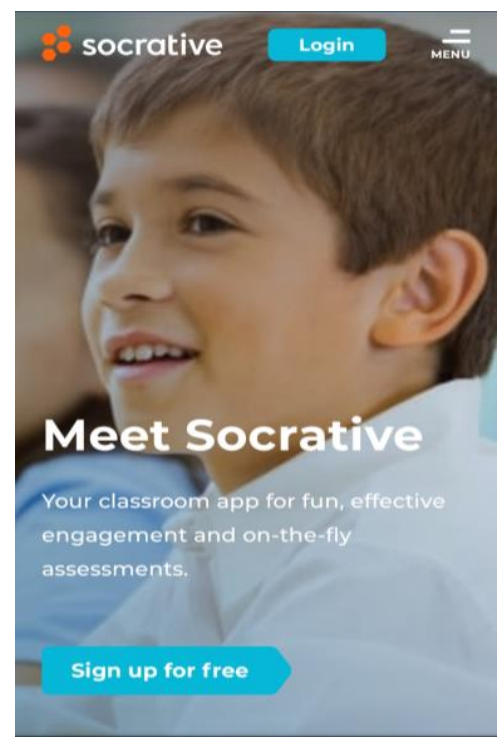

sign up bagi yang pertama kali menggunakannya. Ada dua pilihan penggunaan, free (gratis) ataupun paid (berbayar). Versi berbayar memiliki fitur yang lebih lengkap baik dalam segi jumlah siswa ataupun fitur lainnya seperti rooms (ruang belajar). Fitur gratis hanya menyediakan fasilitas untuk 50 siswa saja dengan satu ruang belajar. Untuk mendapatkan fasilitas lebih, silahkan upgrade ke level pro.

4. Kemudian login dengan email

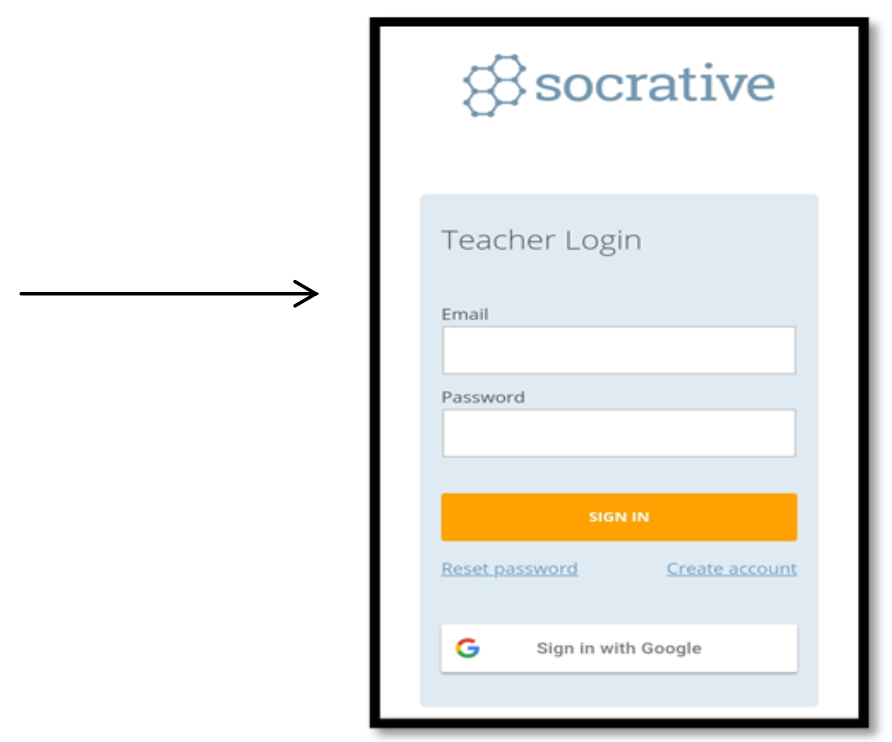


5. Tampilan dashboard socrative dan klik "Quiz"

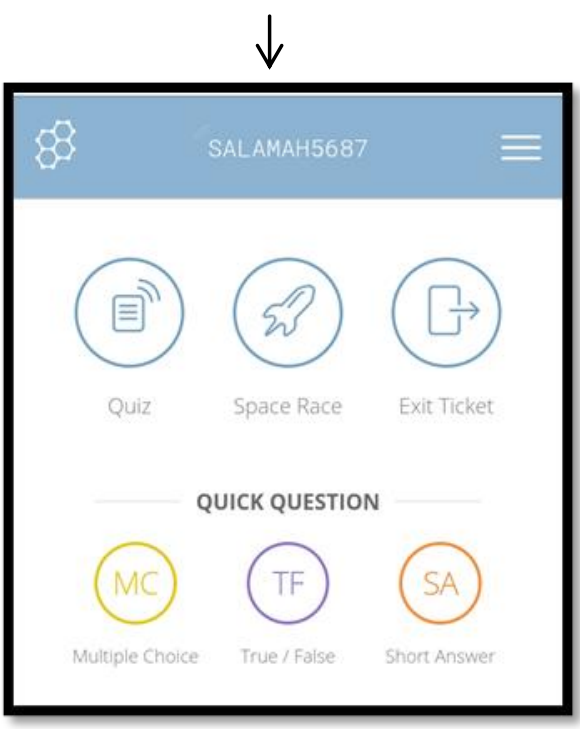

6. Pilih Add Quiz, Klik Create New.

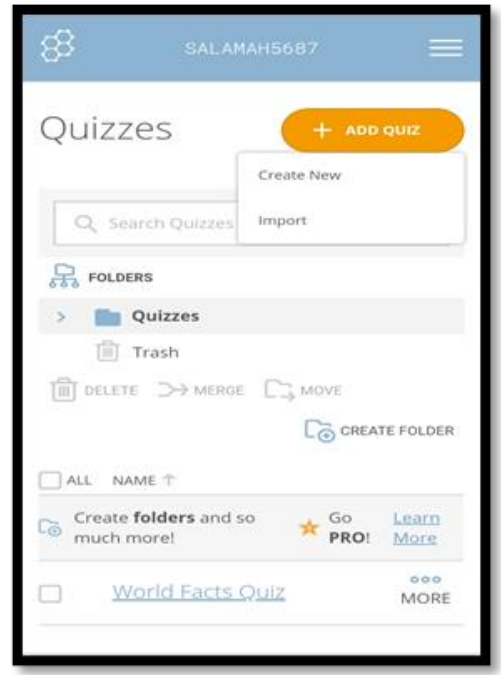

7. Mulailah membuat media pembelajaran bahasa Arab MI, seperti contoh

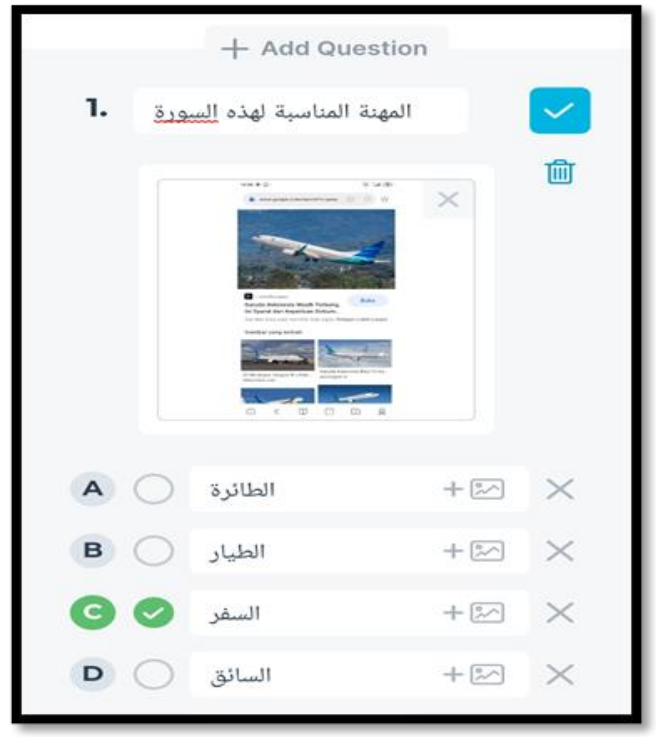

\section{b Sebagai Siswa MI}

Siswa MI bisa menggunakan media melalui smartphone atau laptop untuk mengerjakan latihan-latihan dari Kahoot dengan langkah-langkah sebagai berikut:

\section{Buka browser}




\section{Ketik Socrative Student}

3. Kemudian masukkan "Room Name".

4. Room Name didapat dari guru

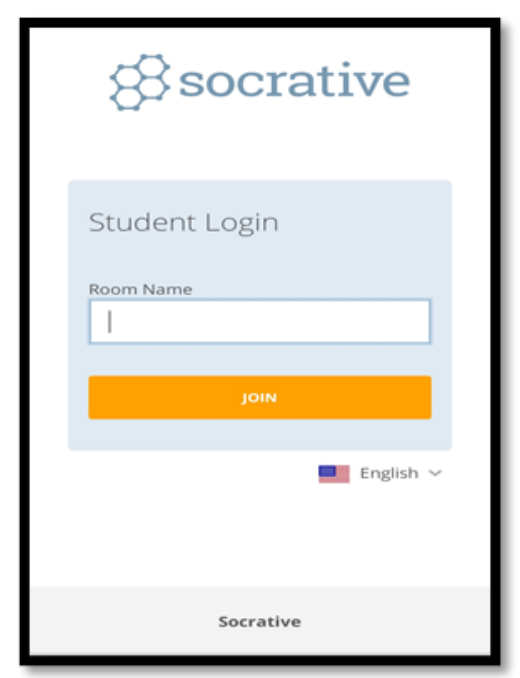

Demikian langkah-langkah cara mengakses dan menggunakan socrative sebagai media pembelajaran bahasa Arab MI.

\section{Kelebihan dan kekurangan Socrative}

Adapun kelebihan dari media pembelajaran kahoot untuk menunjang pembelajaran bahasa Arab MI yaitu Pertama, Pengoperasiannya cenderung mudah, dapat langsung dikerjakan pada gawai milik siswa (Laptop, HP). Kedua, Bisa menyiapkan soal offline terlebih dahulu, Ketiga, Partisipasi siswa termonitor. Keempat, Pengolahan nilai otomatis, Kelima, Siswa tidak perlu membuat akun khusus. ${ }^{19}$ Sedangkan kekurangan dari media pembelajaran kahoot sendiri ada beberapa hal yang akan di rasakan oleh guru dan siswa MI yaitu Pertama, harus ada koneksi internet, baik di perangkat guru maupun siswa. Kedua, perangkat untuk masing-masing guru dan siswa.

\section{Kesimpulan}

Media pembelajaran merupakan sesuatu yang penting dan mesti dimiliki atau dilakukan oleh guru. Hal ini disebabkan karena pembelajaran akan lebih hidup dan bermakna. Berbagai inovasi dalam media pembelajaran diharapkan dapat memberikan motivasi kepada siswa agar lebih giat dan senang belajar. Seperti yang telah dipaparkan, pada hakekatnya sifat inovasi itu amat relatif, dalam arti inovasi yang kita lakukan sebenarnya barangkali sudah tidak asing bagi orang lain. Tetapi sebagai seorang guru yang setiap hari berinteraksi dengan anak, maka tidaklah salah apabila terus menerus melakkukan inovasi media dalam pembelajaran.

\footnotetext{
${ }^{19}$ http:www.jurnalguru21.com/2019/12/tutorial membuat ujian online gratis dan mudah diakses 12 November 2020
} 
Dengan media kahoot dan socrative tersebut diharapkan dapat memberikan dorongan kepada siswa agar lebih semangat dan senang belajar bahasa arab. Sebagai seorang guru yang setiap hari berinteraksi dengan siswa, maka tidaklah salah apabila terus-menerus melakukan inovasi dalam pembelajaran. Memasuki era 4.0 ini, guru dituntut untuk terus mencoba menemukan, menggali dan mencari berbagai terobosan, pendekatan, metode dan media pembelajaran merupakan salah satu penunjang akan munculnya berbagai media baru yang segar dan mencerahkan. Semakin kreatif dan inovatif seorang pengajar dalam menggunakan media pembelajaran akan memudahkan dalam menyampaikan pelajaran bahasa Arab, semakin mudah murid menerima pelajaran bahasa Arab. Hal tersebut merupakan faktor utama keberhasilan pelajaran bahasa Arab jenjang MI.

\section{Daftar Referensi}

Albantani, Azkia Muharom, "Pembelajaran Bahasa arab di MI" Attadib Journal Of Elementary Education, Vol. 3 (2), Desember 2018.

Arsyad, Azhari. Media Pembelajaran. Cet-17. (Jakarta: PT. Grafindo, 2014)

Azzuhri, Muhandis. "Metode dan Media Pembelajaran Bahasa Arab Berbasis Internet di Era Teknologi Informasi." INSANIA: Jurnal Pemikiran Alternatif Kependidikan 14.3 (2009): 348-445.

Haling, Abdul. Perencanaan Pembelajaran. Cet-4. (Makasar: Badan Penerbit UNM, 2017)

Irma Rasita Gloria Barus, Tatie Soedewo, Tanpa tahun, Penggunaan Media Kahoot! Dalam Pembelajaran Struktur Bahasa Inggris, ISSBN: 978-602-71928-1-2

Maknun, Moch Luklil, "Buku Bahasa Arab MI di Pekalongan", Jurnal Penelitian, Vol. 11, Mei 2014.

Marxel Susanto, Zenius.net 2019, diakses hari jumat tanggal 13 November 2020

Mulyasa, Menjadi Pengajar Profesional Menciptakan Pembelajaran Kreatif dan Menyenangkan, (Bandung: PT Rosda Karya, 2008).

Nurjanah, Siti. "Pengembangan Media Pembelajaran Teka-Teki Silang (Tts) Pada Pembelajaran Tematik Tema Cita-Citaku Kelas IV Di MI Al Busyro." PREMIERE: Journal of Islamic Elementary Education 2.1 (2020): 31-42.

Pradana, Akhmad Aji \& Jazilatul Ummah. (2020). PENGARUH MEDIA SEMPOA TERHADAP KEMAMPUAN OPERASI HITUNG PENGURANGAN SISWA KELAS II MI . PREMIERE : Journal of Islamic Elementary Education, 2(1), 94-102.

Riyana, Cepi, "Strategi implementasi Teknologi Informasi dan Komunikasi dengan menerapkan Konsep Instructional Technology”, Jurnal Edutech, Jurusan Kurtek Bandung, 2004. 
Rusyan A. Tabrani, 1993. Proses Belajar - Mengajar yang Efektif Tingkat Pendidikan Dasar. Penerbit: Bina Budaya: Bandung.

Sanjaya, Wina. Strategi Pembelajran Berorientasi Standar Proses Pendidikan, (Jakarta: Prenada Media Group, 2006)

Sudjana, Nana \& Riva, Ahmad, Media Pembelajaran, (Bandung: Sinar Baru Algensindo, 2009).

Supriyono, pentingnya media pembelajaran untuk meningkatkan Minat belajar siswa sd. Volume II, Nomor 1, Mei 2018. PGSD, FIP, Universitas Negeri Surabaya.

Tarigan, Jago, Tehnik Pengajaran Ketrampilan Berbahasa, (Bandung: Angkasa, 1984).

www, ahza.net/2019, diakses hari jumat tanggal 13 November 2020.

http:www.jurnalguru21.com/2019/12/tutorial membuat ujian online gratis dan mudah diakses 12 November 2020 